\title{
An Inquiry on the Effect of Knowledge Management and Strategic Leadership on Dynamic Capability, Entrepreneurship Strategy and Organizational Performance in the General Public Hospitals.
}

\author{
Najmi Kamariah ${ }^{1}$, M.S. Idrus ${ }^{2}$, M. Asdar ${ }^{3}$, Indrianty Sudirman ${ }^{4}$ \\ ${ }^{I}$ School of Administration (STIA) LAN, Makassar, Indonesia \\ ${ }^{2}$ Faculty of Economics and Business, Brawijaya University, Malang, Indonesia \\ ${ }^{3}$ Faculty of Economics and Business, Hasanuddin University, Makassar, Indonesia
}

\begin{abstract}
Organizational dynamic capability and entrepreneurship strategy are two aspects that have contribution in affecting organizational performances particularly by means of knowledge management and strategic leadership. There is a need to identify this presumption, thus current research in this paper were employed in the General Public Hospitals in Makassar in the Provinces of South Sulawesi (Indonesia). Previous research has uncovered important factors of organizational performance such as knowledge management, strategic leadership, dynamic capability, entrepreneurship strategy. Nonetheless they require further conceptual depth and empirical assessment as it remains unclear how these factors holistically affects critical performances in organizational performances. In this paper, we developed the structural model including the introduction of knowledge management and strategic leadership and the more established relationship between dynamic capability and strategic entrepreneurship with organizational performances as a means to understand their interrelatedness and feasibility on improving the body of knowledge in current literature.
\end{abstract}

Keywords - Knowledge Management, Strategic Leadership, Dynamic Capability, Entrepreneurship Strategy, Organizational Performance

\section{INTRODUCTION}

The fast-changing and complex environment brings about the changing paradigm in healthcare particularly hospital's services in Indonesia. This state of affairs becomes major challenges toward hospital's management in order to maintain their continuing existence. To be able to compete and to survive, hospital's leader must be aware of the factors that determine organizational performance and existences. Therefore, those who become leaders in this healthcare facility must strive to increase their capability to spearhead the development of their hospital in order to keep expanding, adaptive, and responsive in accordance with the demand that comes from environmental development, particularly the changing stakeholder's view.

Hospitals in the city of Makassar, which is the largest city in Eastern Provinces of Indonesia, have also been affected by environmental changes. The intensity of competition is becoming more frequent with the increasing number of new hospitals that operate in particular private hospital. The competition becoming more intense as many new hospital claims to be an international standard hospitals, which are generally equipped with the latest advanced medical equipment and luxurious facilities such as hotels. Increasing trend in hospital development could have been triggered by the entry of foreign investors, the development of the upper middle class population, improvement in the level of income per capita, and community that in large become more critical in maintaining their health and choose where to seek treatment.

In such circumstances, the hospital management requires a management system that is able to anticipate changes in such dynamic environments. Especially for government hospitals, with regional autonomy legislation aimed at reducing reliance on government subsidies, the hospital must attempt to maintain its existence, while striving to be more advanced and able to improve their image, and has optimal competitiveness to cope with regional and global competition. In the context of sustainability, general public hospital's ability to be able to prepare their own sustainable source of income becomes important. Even though there is a sponsor or investors that have interest in investing, criteria or requirements imposed on investment is too often relies heavily on the readiness and ability of hospitals to seek their own sources of income, as an indicator of organizational sustainability.

As one of the government agencies working in the health sector, the general public hospital leaders must realize that the hospital must conduct internal restructuring and business process improvement and management of human resources. The act of entrepreneurship in the business sector should be implemented in the public sector; including general public hospitals, so that they could compete and be able to explore the 
opportunities present in the external environment that are constantly evolving. Therefore, entrepreneurial strategy is seen as an important way for competitive advantage and improved organizational performance.

Competitive advantage is derived from the value that can be created for customers that exceed the costs incurred to create value [1]. It is commonly acknowledged that this is not an easy task to achieve, particularly for hospitals as they are traditionally thought of as economic and social institutions that must balance the demands of accountability of various stakeholders. These require extra effort, given the intensity of competition in the domestic and global level that has increased sharply in the current knowledge economy era. Thus, the management of the hospital should be able to create an organization that is able to generate superior performance, providing satisfactory service to customers or patients and in the same time to meet the expectations of stakeholders.

The general policy of the Government of Indonesia c/q Ministry of Health's Hospital Strategic Policy and Program Services, have requiring that hospital embrace Economic - Equity - Quality as their oriented principles. In the sense that each hospital organization must be managed effectively and efficiently (Economic), serving all levels of society rich and poor (Equity) and give their service in a professional and quality means (Quality). As also set forth in the Government of Indonesia Act on health that every head of administration in the public health facilities and individual health should have the needed community and individual management competencies individuals (Article 33 and 34 of the Government of Indonesia Decree No. 28 of 2009 on health) [2]. As for the public hospitals which have become relevant Public Service Agency (Badan Layanan Umum BLU), it have been determined that it is mandatory that BLU must have five-year strategic plan with reference to the Strategic Plan of the Ministry of State / Agency or Medium Term Development Plan (PP. 23 on Financial Management BLU) [3]. While for the the private hospital, the hospital accreditation regulations specified that the first assessment standards are aspects of administration and management, which in essence enforce them to develop a strategic business plan (Rencana Strategi Bisnis - RSB).

In the face of these challenges, there is a call for hospital leaders to increasing their capability in deciding the direction of hospital development so that the hospital could adapt and being innovative in order to survive in a turbulent environment. In such circumstances, the hospital needs to have strategic flexibility to respond to problems quickly. One of the fundamental efforts is to conduct internal restructuring quickly and accurately, professionally managed organizations by service innovations, and to develop hospital that have high mobility, in tune with the increasing demands from their environment. In this case, entrepreneurship strategy could encourage hospital dynamic capabilities hospital that could anticipate the ever-changing condition $[4,5]$

Public sector entrepreneurship then could be foreseen as one of the means or even a "breakthrough" to overcome bureaucratic bottlenecks and deadlocks in public sector organizations. The characteristics of the system in the public sector that tend to be rigid and maintaining their status quo should be able to be disbursed through the transmission of cultural entrepreneurship. Innovations that are usually only familiar in dynamic environments such as in the business sector is believed could also be carefully implemented into the public sector. Positive signal from the changes that already done with regard to the implementation of entrepreneurship in public sectors was positive and making innovation started to get a place in the public sector. This is not independent from the external dynamics and the rapid changes in demands, which occurred outside a public organization. Moreover, this situation requires strategic leadership to bring about change and to develop entrepreneurial culture in the organization.

Entrepreneurship strategy provides an activity roadmap for organizational intended direction to anticipate change and how to achieve these changes [6] Entrepreneurial strategy requires strategic leaders who drive innovation in a rapidly changing environment and uncertain as occurring nowadays [7] . Companies that following entrepreneurship strategy tends to be more developed in the midst of severe competition compared to those without [8].

The relationship between entrepreneurship and firm performance in large organizations has been assessed differently in previous research. Entrepreneurial activity becomes a new means for the company that wants to exploit hidden opportunities or in the face of aggressive competition [9]. Creating a novelty, in terms of new resources, customers, markets, or new combinations of resources, customers, and markets, have become a characteristic of entrepreneurial activity. Entrepreneurship quite rapidly has become very important in the face of changing market structure and industry, including the needs of customers, technology, and social values.

Many factors affect companies' success when they employed entrepreneurship action in implementing corporate entrepreneurship strategy. The most important factor is concerning the ability of the company to build a vision and how top management manage people and tasks, in a way that allows them to support and developing entrepreneurship, and has sufficient resources to support entrepreneurial action, using a system of rewards and compensation that strengthen entrepreneurial individuals and teams, and to encourage risk taking, as measured by the individual's willingness to accept risk and tolerate failure.

Nowadays, organizations need strategic leadership to gain an advantage from uncertainty to become flexible, innovative, creative, and manage entrepreneurship behavior. In spite of this, managing innovation and 
entrepreneurship are complex, full of challenges, and risk. Implementation of innovation and entrepreneurship could not be achieved merely with "lip service" in order to build an entrepreneurship capability and supportive organizational climate; there is a call for more entrepreneurial organizations [9]. The fact is that strategic leadership needs the creation and support of entrepreneurship orientation. Strategic leadership have been allocated by several authors as an approach to drive conducive innovative environment in order to advance organizations, humans, social and structural capability [7]

The role of resources in creating innovation and create competitive advantage tend to favor intangible assets than tangible resources $[10,11]$. Intangible assets, primarily, knowledge is an important organizational intellectual capital to help in the decision making process $[12,13]$, as well as creating value and sustainable competitive advantage $[14,15,16]$. Knowledge within an organization has the greatest ability when compared to other company's resources to provide a sustainable source of differentiation [17]. Organizational knowledge serves as a key input to strategy formulation process and guides the development of manufacturing capabilities to create value in their product [18].

The shape and the organization's ability to manage knowledge (knowledge management) greatly affect the quality of the knowledge produced and the quality of the action or decision from using such knowledge. Knowledge management is rooted in the idea of mobilizing the organization's intellectual resources [19], which, through a process of knowledge management, organizations could reinforce their key intellectual capital [20]. Knowledge management is an essential activity to acquire, grow and retain intellectual capital, so that the successful implementation and use of knowledge management could help ensure the acquisition and growth of intellectual capital.

Previous research has highlights the importance of knowledge management for innovation, performance, and competitive advantage, but the study of knowledge management in public sector organizations are less clearly revealed. In addition, the study of knowledge management in the health services industry is also have been given less attention by previous researchers. This study tries to fill this gap by striving to investigate the influence of knowledge management and strategic leadership on dynamic capabilities, entrepreneurial strategy, and organizational performance particularly the performance of the general public hospital.

Previous researches have confirmed that the performance achieved by the organization comes from the capability of the organization to drive the entire activities of the organization to achieve a competitive advantage. Chen and Huang [21], testing the mediating effect of dynamic capabilities on the relationship between strategic human resources practices and innovation performance. Dynamic capabilities' role as leverage in improving organizational performance and has been realized and desired by all organizations, but it is not well understood. Most of the organization's leaders believe that this dynamic capability is built only in terms of human resources and the process of its creation is very complex [22]. Moreover, empirical studies on the organization of health services, especially hospital still appear to be less discussed. Therefore, this study tries to bridge this gap by analyzing the role of dynamic capabilities in the implementation of organizational entrepreneurship strategy and hospital performance.

From these backgrounds, some things need to be underlined. First, hospital's strategic environment undergoes dynamic changes, which require management to optimize the entire resource of knowledge and capabilities to achieve superior performance. Second, as hospital must have an ability to integrate all the resources and capabilities in order to be able to respond quickly to changes in its strategic environment, there is a need for hospital leader that can drive change and foster entrepreneurial behavior to increase the flow of creativity and innovation throughout the organization members. Finally, the performance achieved by the hospital should be accountable to all stakeholders - patients, community, employees and the government - not just the programs / activities and services provided, but also on accountability for results (outcomes) of all programs and activities performed.

\section{Underlying Conceptual Framework And Hypothesis}

Based on the conceptual framework from relevant previous theoretical and empirical analysis, thus we could formularize the hypotheses for current research as follows:

Knowledge management has strong effect on dynamic capability [23, 24]. Knowledge management determines organizational capability to be able to adapt in haste toward changes occurred in its strategic environment [25,26,27]. Knowledge management capacity has an ability to motivate and supports employee and organizational activity and therefore triggered organizational dynamic capability. Hypothesis 1 is therefore offered in accordance with aforementioned theoretical and empirical analysis.

Hypothesis 1: Knowledge management has significant influence on organizational dynamic capability.

Effective implementation of strategic leadership that supports entrepreneurship strategy is strongly determines by how far organizational capability could responds to changes that occurred in their environment [28]. The success of an entrepreneurship strategy implementation primarily depends on leadership capability to 
determine entrepreneurship vision, and autonomy given from leaders to organizational members to innovate and creative in daily job performances [29,30]. Therefore, we offer Hypothesis 2.

Hypothesis 2: The better an organizational strategic leadership, the better is its entrepreneurship strategy.

The most critical aspects of dynamic capabilities (DC) are company ability to identify market changes, aware of any market needs and opportunities, and then to enact needed transformation by reconfiguring resources and creating value. Major premises in DC are that every organization should utilize and renewed their tangible and intangible assets and capability to achieve sustainable competitive advantage in the fast-changing environment [28, 30,31]. Dynamic capability could not stand alone to become the only source for sustainable competitive advantage, dynamic capability must have contribution toward the attainment of superior company performance by merging and renewing functional competence that in turn would have an effect on performance [32]. Briefly, we could state that dynamic capability build and reconfigure position of any firm resources [22], routine operations [31] or operational capability [32] and through them have effect on performance [28]. This causality chains exhibit an indirect relationship between dynamic capability and organizational performance. Hypothesis 3 is offered.

Hypothesis 3: The better an organization's dynamic capability, the better is its organizational performance.

Relationship between entrepreneurship strategy and company performance in bigger organization have mixed assessment overtime [8,9]. During 1980s, some commented that it is difficult for a person to perform entrepreneurially in a bureaucratic organizational structure. At the same time, others believe that firm of any type and size could perform entrepreneurship action, and this in turn would improve company performance.

Many factors have influence on company success when employing entrepreneurship action in performing corporate entrepreneurship strategy $[8,9,33]$. The most important factors are company's ability to build upon their vision and how top management manages people and tasks with any means possible to uphold entrepreneurship action to develop by having sufficient resources to support this entrepreneurship action. In addition, utilization of the reward system and compensation that could strengthen entrepreneurship team and individuals to drive risk taking and measured by individual willingness to receive risk and tolerate any failures was also important in this endeavor [9,33]. Hypothesis 4 is therefore stated.

Hypothesis 4: The better an implementation of entrepreneurship strategy, the higher is its organizational performance.

Teece et al. [28] define dynamic capability concept as, “....another component of the efficiency-based approach to identify the dimensions of firm-specific capabilities that can be sources of advantage, and to explain how combinations of competences and resources can be developed, deployed, and protected." Moreover, Teece et al. [28] explain that, "...the term dynamic refers to the capacity to renew competences so as to achieve congruence with the changing business environment; certain innovative responses are required when time-tomarket and timing are critical, the rate of technological change is rapid, and the nature of future competition and markets difficult to determine". Meanwhile, "the term capabilities emphasizes the key role of strategic management in appropriately adapting, integrating, and reconfiguring internal and external organizational skills, resources, and functional competences to match the requirements of a changing environment". Therefore, we could restate that dynamic capability is a subset of the total resources that enable firm to create new product and process. Dynamic capability is a pattern of collective activity in which organizations systematically produce and modifies resources and organization routines in an effort to improve effectiveness to meet changing market environment [28, 30,31].

Dynamic capability approaches particularly focus on how to manipulate future knowledge resources [34]. Dynamic capability put an emphasize on resources that could improve the rate of original change and strategic adaptive pattern in the future, which in turn would drive entrepreneurship strategic process in a firm [28]. Dynamic capability could triggered strategic leadership process, which is in the form strategic action that spearhead toward creating sustainable competitive advantage [9]. Therefore, we offered Hypothesis 5:

Hypothesis 5: The better an organization's dynamic capability, the better is its implementation of strategic entrepreneurship.

Superior company performances depend on their ability to innovate, protect its intangible asset (knowledge), and to deploy this asset [36]. Empirical analysis by Choi et al. [37] proved that organization that simultaneously employed higher external-oriented and internal-oriented knowledge management strategy would achieve higher organizational performance. Moreover, Yang et al. [38] proved that knowledge management as key success factors have positive relationship with organizational performances. Knowledge management have a positive relationship with organizational effectiveness [24,25,26,27,39,40], and significant influence on new product development performance [41], and competitive advantage [42,43]. Based on previous concepts and indications from previous researches, we could propose Hypothesis 6.

Hypothesis 6: The better knowledge management, the higher is its organizational performance.

Every leader must be able to maintain a means so that organization could add value and cope with changes that reside within or outside organization, and present challenges and opportunities in an effort to 
increase value [44]. Effective strategic leadership could unearth whether strategic crafts and executions is well implemented that enable strategic resources to give advantage to survive in a turbulent economic environment.

Furthermore, it was suggested that when organizational leader manage resources effectively and put emphasize on product differentiation and integrations of all people, they would have good performances and gain superior profit [30]. Therefore, out of these supportive arguments the following hypothesis 7 is proposed. Hypothesis 7: The better an organizational strategic leadership, the higher is its organizational performance.

Knowledge management and dynamic capability drive toward an attainment of better performance when they support operational function of a firm. In coping with the challenges from the environment that become more turbulent, organizations must be more adaptive and responsive and strive to nurture organizational capability to improve organizational performance, which become the source of organizational competitive advantage. Organization that develops organizational capability continuously could gain higher rate of innovation performance $[45,46,47,32]$. Knowledge management enables dynamic capability as an antecedent from certain operational or functional competence that in turn would have significant impact on organizational performance [23,24,48]. Hypothesis 8 and Hypothesis 9 is therefore stated.

Hypothesis 8: Dynamic capability has mediates effect in the influence of knowledge management on organizational performance.

Hypothesis 9: Entrepreneurship strategy has mediates effect in the influence of strategic leadership on organizational performance.

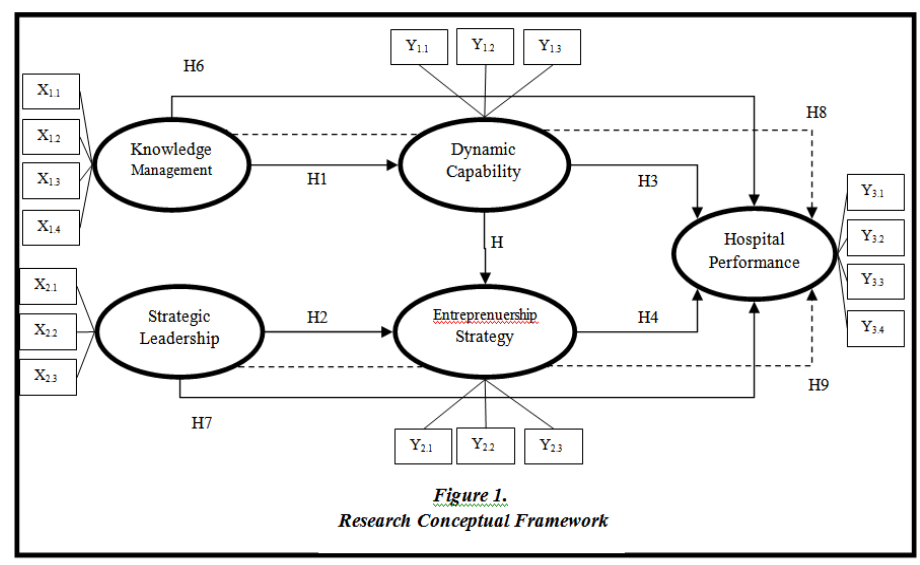

\section{RESEARCH METODOLOGY}

A research in this paper is in the form of explanatory research or confirmatory research that has an objective to inquiry a relationship between one variable and other variables, or exploring how a variable(s) have effect on other variable(s) [49], therefore each variable defines its own dimensions and has varied influence on organizational performance. However, the strength and direction of relationship would be measured to identify the type and intensity of the relationship, therefore, the research is exploratory in nature [50,51].

We performed structural equation analysis or Structural Equation Modeling or SEM [52]. The data received from the respondents was analyzed with help of statistical software program SPSS, which then become an input for the hypothesis testing in AMOS 18 [50,51,52,53]. The data for this study included four general public hospital that owns by the central government (RSU Wahidin, a type A hospital), general public hospital owns by local South Sulawesi's government (RSUD Labuang Baji and RSUD Haji, a type B hospital), and general public hospital owns by City of Makassar's government (RSUD Daya, a type C hospital) [54].

Population in this research is all of the leaders in the hospital that based in the structural or functional unit in the aforementioned hospitals that become the location of our research. Furthermore, from this population we extract samples according to the procedures stated in the SEM analysis [50,51,52]. Collection of data in a fixed time and normal situations put our data in in the form of cross-sectional data. Table 1 reveals the distribution of respondents in our sample from the four participating hospitals.

Table 1. General Public Hospital Leaders in the Sample

\begin{tabular}{|l|l|l|l|}
\hline Number & Hospitals & Owners & Respondents \\
\hline 1 & RS Wahidin Sudirohusodo & Ministry of Health & 63 \\
\hline 2 & RSUD Labuang Baji & Government of the Provinces of South Sulawesi & 50 \\
\hline 3 & RSUD Haji & Government of the Provinces of South Sulawesi & 17 \\
\hline 4 & RSUD Daya & Government of the City of Makassar & 39 \\
\hline Total & & 169 \\
\hline
\end{tabular}

Source: Primary Data, 2012 
Responses from respondents on the indicator of variable knowledge management, variable strategic leadership, variable dynamic capability, variable strategic entrepreneurship, and variable hospital performance or RSUP/RSUD performance was measured on five-point Likert scale that is classified as an interval data.

Measurement technique for the research variable is by assigning a score weight to each response given by respondent as follows: (1) "strongly disagree/never", (2) "disagree/ever", (3) "neutral/seldom", (4) "agree/often", and (5) "strongly agree/always". Interval data scale have been possible due to the data have been shown to have an interval, yet to do not have an absolute zero (ratio scale) and also have more than categorical meanings (ordinal). And second, this interval data scale is a perquisite to use multivariate analysis (SEM), in which SEM analysis requires that the minimum data type is metrics (interval or ratio) as suggested by Solimun [55].

\section{RESEARCH FINDINGS AND DISCUSSION}

In line with the empirical model proposed in current study, we performed a series of test on previous hypothesis by means of path coefficient in the structural equation model. Table 2 is the hypothesis testing by looking at the $\mathrm{p}$ value, if $\mathrm{p}$ value is less than $0.05(\mathrm{p}<0.05)$ then there is a significant relationship between variables. Table 2 shown results of testing the hypothesis with path analysis.

Table 2. Estimated Results of the Path Analysis

\begin{tabular}{|c|c|c|c|c|c|c|}
\hline \multicolumn{7}{|c|}{ Direct Effect } \\
\hline $\begin{array}{l}\text { Hypo- } \\
\text { thesis }\end{array}$ & $\begin{array}{l}\text { Independe } \\
\text { nt Variable }\end{array}$ & $\begin{array}{c}\text { Dependent } \\
\text { Variable }\end{array}$ & $\begin{array}{l}\text { Standar- } \\
\text { dized } \\
\text { Value } \\
\text { (b) }\end{array}$ & CR & $p$-value & Notes \\
\hline 1 & $\begin{array}{c}\text { Knowledge } \\
\text { Manageme } \\
\text { nt }\end{array}$ & $\begin{array}{l}\text { Dynamic } \\
\text { Capability }\end{array}$ & 0.855 & $\begin{array}{c}5.93 \\
6\end{array}$ & 0.000 & $\underset{\mathrm{t}}{\text { Significan }}$ \\
\hline 2 & $\begin{array}{c}\text { Strategic } \\
\text { Leadership }\end{array}$ & $\begin{array}{c}\text { Entreprene- } \\
\text { urship } \\
\text { Strategy }\end{array}$ & 0.257 & $\begin{array}{c}2.48 \\
8\end{array}$ & 0.013 & $\underset{\mathrm{t}}{\text { Significan }}$ \\
\hline 3 & $\begin{array}{l}\text { Dynamic } \\
\text { Capability }\end{array}$ & $\begin{array}{c}\text { Hospital } \\
\text { Performanc } \\
\mathrm{e}\end{array}$ & 0.626 & $\begin{array}{c}2.46 \\
3\end{array}$ & 0.014 & $\begin{array}{c}\text { Significan } \\
\mathrm{t}\end{array}$ \\
\hline 4 & $\begin{array}{c}\text { Entreprene- } \\
\text { urship } \\
\text { Strategy }\end{array}$ & $\begin{array}{c}\text { Hospital } \\
\text { Performanc } \\
\mathrm{e} \\
\end{array}$ & 0.378 & $\begin{array}{c}2.09 \\
0\end{array}$ & 0.037 & $\begin{array}{c}\text { Significan } \\
\mathrm{t}\end{array}$ \\
\hline 5 & $\begin{array}{c}\text { Dynamic } \\
\text { Capability }\end{array}$ & $\begin{array}{c}\text { Entreprene- } \\
\text { urship } \\
\text { Strategy }\end{array}$ & 0.640 & $\begin{array}{c}4.90 \\
0\end{array}$ & 0.000 & $\begin{array}{c}\text { Significan } \\
\mathrm{t}\end{array}$ \\
\hline 6 & $\begin{array}{c}\text { Knowledge } \\
\text { Manageme } \\
n t\end{array}$ & $\begin{array}{c}\text { Hospital } \\
\text { Performanc } \\
\text { e }\end{array}$ & -0.117 & $\begin{array}{c}- \\
0.61 \\
2 \\
\end{array}$ & 0.541 & $\begin{array}{c}\text { Not } \\
\text { Significan } \\
\mathrm{t}\end{array}$ \\
\hline 7 & $\begin{array}{c}\text { Strategic } \\
\text { Leadership }\end{array}$ & $\begin{array}{c}\text { Hospital } \\
\text { Performanc } \\
\text { e }\end{array}$ & 0.133 & $\begin{array}{c}1.17 \\
0\end{array}$ & 0.242 & $\begin{array}{c}\text { Not } \\
\text { Significan } \\
t\end{array}$ \\
\hline \multicolumn{7}{|c|}{ Indirect Effect } \\
\hline $\begin{array}{l}\text { Hypo- } \\
\text { thesis }\end{array}$ & $\begin{array}{l}\text { Independe } \\
\text { nt Variable }\end{array}$ & $\begin{array}{c}\text { Dependent } \\
\text { Variable }\end{array}$ & \multicolumn{2}{|c|}{$\begin{array}{c}\text { Intervening } \\
\text { Variable }\end{array}$} & $\begin{array}{l}\text { Standar- } \\
\text { dized } \\
\text { Value } \\
\text { (b) }\end{array}$ & Notes \\
\hline 8 & $\begin{array}{c}\text { Knowledge } \\
\text { Manageme } \\
\text { nt }\end{array}$ & $\begin{array}{c}\text { Hospital } \\
\text { Performanc } \\
\text { e }\end{array}$ & \multicolumn{2}{|c|}{$\begin{array}{c}\text { Dynamic } \\
\text { Capability }\end{array}$} & 0.594 & $\begin{array}{c}\text { Significan } \\
\mathrm{t}\end{array}$ \\
\hline 9 & $\begin{array}{c}\text { Strategic } \\
\text { Leadership }\end{array}$ & $\begin{array}{c}\text { Hospital } \\
\text { Performanc } \\
\text { e }\end{array}$ & \multicolumn{2}{|c|}{$\begin{array}{c}\text { Entrepreneurship } \\
\text { Strategy }\end{array}$} & 0.074 & $\begin{array}{c}\text { Significan } \\
\mathrm{t}\end{array}$ \\
\hline
\end{tabular}

\section{Source: Primary Data, 2012}

In overall from all of the nine hypotheses tested in the path analysis, seven paths are significant, whereas the other two paths are not significant. The hypothesis tested statistically is discussed separately as follows:

a. Knowledge management have a significant influence on dynamic capability $(b=.855 ; p=0.000<0.05)$, thus hypothesis 1 is supported. Employment of knowledge management has positive significant influence on organizational dynamic capability. This result give an indication that good practice of knowledge management in the form of knowledge acquisition, knowledge dissemination within an organization, knowledge storing, and knowledge application bring hospitals to earn dynamic capability, which indicates by its quick ability to adapt, to structure their capability, and have powerful inter-functional team in solving 
organizational problems. Current findings also show that the better knowledge management implementation, the better is its organizational dynamic capability.

b. Strategic leadership have significant influence on entrepreneurship strategy $(b=.257 ; p=0.013<0.05)$. This result shown that the better an organizational strategic leadership, the better is its entrepreneurship strategy, thus we could state that we support hypothesis 2 . This finding shown that implementation of good strategic leadership in hospital would push forward entrepreneurial spirit within their employees. Therefore, strategic leadership has positive significant influence on the implementation of entrepreneurship strategy.

This means that implementation of entrepreneurship strategy primarily depends on a vision of the hospital leader. The actualization of this emerging positive influence supports by visionary leader in the attainment of effective working environment would enact balanced control over organizational resources, which would have an impact on successful implementation of entrepreneurship strategy and innovation process within an organization.

c. Organizational dynamic capability have a significant influence on hospital performance $(b=.626 ; p=0.014$ $<0.05$ ), thus hypothesis 3 is supported. This result shown that the better an organization's dynamic capability, the better is its organizational performance (in term of the performance of the RSUP/RSUD). Current findings also explicitly imply that dynamic capability have contributions toward the attainment of organizational performance. The occurrence of positive influence due to the integration of all organizational resources in their programs and activities, which would enable organization to be adaptive in coping with the emerging changes in organizational external environment, the changes in government regulation, sociocultural development within the society, and the changing demand of their customer who become more critical from day to day. Dynamic capability of the hospital proven to be able to improve organizational performance, particularly those related to the financial aspect, customer satisfaction, operational process (quality of service), and development and learning (employee performance and satisfaction).

d. Entrepreneurship strategy have a significant influence on hospital performance $(b=.378 ; p=0.037<0.05)$. This result shown that the better implementation of entrepreneurship strategy, the higher is its organizational performance, thus we could state that we support hypothesis 4 . The positive coefficient (b) implicitly showed an emergence of powerful inter-functional team that always strive to be innovative in an organization in the form of organizational operation innovative process or innovation on servicing their product. Therefore, implementation of entrepreneurship strategy would bring contribution toward achieving organizational performance.

e. Dynamic capability have a significant influence on entrepreneurship strategy $(b=.640 ; p=0.000<0.05)$, thus hypothesis 5 is supported. This result shown that the better an organization's dynamic capability, the better is its implementation of entrepreneurship strategy.

f. Knowledge management do not have significant influence on hospital performance $(b=-.117 ; p=0.541>$ 0.05), therefore contrary to expectations, hypothesis 6 is not supported. This negative coefficient (b) shown that good knowledge management could not directly advance hospital performance (in term of the RSUP/RSUD performance). Yet, knowledge management inhibits an indirect influence via dynamic capability with a standardized coefficient value (b) of .594. This implies that knowledge management would drive an increase in dynamic capability that in turn has an effect on enhancing hospital performance.

g. Strategic leadership do not have significant influence on hospital performance $(b=-.133 ; p=0.242>0.05)$, therefore contrary to expectations, hypothesis 7 is not supported. This negative coefficient (b) implies that good knowledge management could not have direct influence on enhancing hospital performance. In spite of that, strategic leadership inhibits an indirect influence by means of entrepreneurship strategy with a standardized coefficient value (b) of .074. This implies that strategic leadership would improve entrepreneurship strategy that in turn has an effect on increasing hospital performance.

h. According to the findings in Table 2, implementation of knowledge management could improve organizational performance by means of increasing organizational dynamic capability $(b=.594)$. This positive coefficient (b) shown that dynamic capability has mediates effect in the influence of knowledge management on organizational performance (RSUP/RSUD performance), therefore support was found for Hypothesis 8. Dynamic capability has complete mediation over the influence of knowledge management on organizational performance. Current findings implies that good implementation of knowledge management do not directly determine organizational performance, yet its existence become important input in an attainment of dynamic capability improvement in an effort to increase organizational performance.

i. Strategic leadership also has an indirect influence on improving organizational performance. As explicitly shown in Table 2, implementation of entrepreneurship strategy has complete mediation over the relationship between strategic leadership and organizational performance $(b=0.074)$. This positive coefficient (b) implies that entrepreneurship strategy has mediates effect in the influence of strategic leadership on organizational performance, thus we could support Hypothesis 9. This finding depicted that strategic leadership is not in the position to do not directly determine organizational performance, 
nevertheless successful implementation of entrepreneurship strategy in improving organizational performance might well be effected by the implementation of strategic leadership.

\subsection{Role of Dynamic Capability as Mediating Variable in the Indirect Effect of Knowledge Management on Organizational Performance}

In accordance with our variable testing (Hypothesis 8), it was proven that indirect effect of knowledge management on organizational performance by means of organizational dynamic capability (as mediating variable) is significant, whereas direct effect of knowledge management on organizational performance without including variable dynamic capability is not significant (Hypothesis 6). This supports our notion that organizational dynamic capability has complete mediation over the influence of knowledge management on organizational performance. Current findings corroborates that knowledge management is not directly determines organizational performances, nevertheless its existences is a key determinant to dynamic capability toward maintaining or improving organizational performance. Consequently, these give an indication that organizational knowledge about the external and internal conditions that created by means of knowledge management process could maintain organizational performance via organizational dynamic capability.

Moreover, this dynamic capability is measured through indicators such as continuous organizational capability to be adaptive toward environmental changes, flexible organizational structural capability, and organizational capability to integrate all of the resources in the business process.

Hence, to maintain their survivability, hospitals must give emphasize on both knowledge management and dynamic capability as an organizational strategic capability in an effort to improve tasks and functions of hospitals as the social business institution. Hospitals must completely comprehend the knowledge about their external and internal conditions and thoughtfully utilize this knowledge in an effort to improve hospital ability to be able to deal with threat from more complex and unpredictable environmental changes. It is shown that knowledge management and dynamic capability not only become interrelated functions that make up valuable organizational capability, but together they also have positive implication on organizational performance.

Current findings is in line with an abundance of previous research that have studied the relation between knowledge management, dynamic capability, and performance $[23,24,31,32,41]$. Holm and Sharma [56] in particular inquire the indirect effect of subsidiary marketing knowledge application on MNC performance by means of strategic decisions in the form of technological development and market expansion. In which they found that the application of the subsidiary marketing knowledge have influence on strategic decision in MNC in their effort to develop technology (new product innovation and production process) and market expansion and in turn have real contribution on MNC performances. This result shown that MNC strategic decision mediates the influence that knowledge application have on MNC performances as MNC strategic decision function as partial mediation variable, which are different than the findings of current research as dynamic capability is found as complete mediation variable.

Whereas Liu et al. [41] in their research, study the relations between knowledge management method, new product development (NPD) strategy, and NPD performances. Their findings proved that knowledge management method has significant roles on the entire aspect of NPD strategy, and that this NPD strategy showed a significant positive influence on NPD performances. Thus in Liu et al. (2005), NPD strategy mediates knowledge management method influences on NPD performance. In congruence with the findings from Holm and Sharma [56], in their inquiry, there is a proof that the direct effect of knowledge management method on NPD performance was significant; therefore, NPD strategy could be viewed as partial mediation to the influence between knowledge management and performance.

Comparison made between current researches with the two previous researches shown that there is a minor difference in the role of mediating variable. In our analysis, we viewed dynamic capability as having complete mediation, whereas in the two previous researches, strategic decision (NPD strategy and MNC strategic decision) are partially mediating the relation between knowledge management and organizational performance. The existence of these differences does not lessen the essence of knowledge management and strategic decision as important organizational resources; particularly if we note that the integration of these two variables into organizational strategic capability is valuable and finally could improve organizational competitiveness.

One important finding that we could comprehend in relation with previous researches $[24,41,56]$ in examining the interconnectedness between knowledge management, dynamic capability, and organizational performance is the existence of reciprocal relationship between knowledge management and dynamic capability $[23,28,36]$. Integration between knowledge management and dynamic capability could have a complete reciprocal effect to become valuable organizational capability in an effort to maintain organizational performance [46,47]. Therefore, current results corroborate the resource-based view (RBV), that combination from several resources could give competitive advantage potential and resulting in superior performances $[25,26]$. 


\subsection{Role of Entrepreneurship Strategy as Mediating Variable in the Indirect Effect of Strategic Leadership on Organizational Performance}

A result from mediating variable testing (Hypothesis 9) about the role of entrepreneurship strategy in the influence between strategic leadership on organizational performance is significant. Nevertheless, a direct effect of strategic leadership on organizational performance without involving variable entrepreneurship strategy is not significant (Hypothesis 7). Therefore, current findings support our conception that entrepreneurship strategy completely mediates the effect of strategic leadership on organizational performance. The better an organizational strategic leadership in driving the entire potential organizational resources in the implementation of tasks and hospital functions, the higher is its organizational performance by means of well and suitable implementation of entrepreneurship strategy.

Current findings shown that strategic leadership is not directly determines the improvement of organizational performance, yet strategic leadership becomes key determinant for implementing entrepreneurship strategy to achieve better organizational performance [9,33,57]. As organizational strategic leadership is improving, the better is its organizational performance through the implementation of entrepreneurship strategy. Moreover, this entrepreneurship strategy is indicated by the existence of interfunctional team that has the ability to develop various operational process and medical services, and new product services. These findings give proof that within any organization, the role of leader is strategic in an effort to increase organizational capability in implementing and executing strategy into various program and integral actions.

By means of this organizational capability, organization could increase or maintaining their performances in four aspects: financial, customer, operational process, and learning and growth $[58,59]$. These conditions are very much depends on the role of strategic leadership in driving and motivates the entire organizational resources to give their best contribution in coping with the challenges from organizational environment that become more complex and turbulent [8,30]. With this role, leaders could improve organizational capability in implementing strategy and have positive impact on the attainment of organizational performance as implied in Fairholm [29]. Moreover, he also shown that strategic leadership has a role in improving organizational performance by contributing its ability to execute strategy. Although have a different insights from Fairholm [29], yet from the perspective of RBV and its approaches [25,26,34], current result shown that strategic leadership could be thought of as the source of organizational capability to produce strategy execution. Thus, current results is more suitable and in line with RBV, as this capability become valuable capability and not easily imitable in an effort to attain better organizational performance that become the source for competitive advantage $[18,19]$.

\section{RESEARCH CONTRIBUTIONS AND LIMITATIONS}

Interesting and important findings from current inquiry have proven that knowledge management and strategic leadership become important organizational intangible resources to be able to implement better and suitable strategy. Moreover, knowledge management in essential have been proven as important resources for executives to improve their capability in their roles and being able to be the active participants in the formulation of organizational strategic issues.

Current inquiry reveals that knowledge management and strategic leadership corroborates the notion that they are not direct determinant for increasing organizational performance, yet their contribution toward organizational performance are achieved through dynamic capability and implementation of entrepreneurship strategy. Strategy execution that is grounded by knowledge management and strategic leadership could become valuable and hard to imitate organizational strategic capabilities that become the source for organizational competitive advantage.

\subsection{Theoretical Contributions}

This study contributes to the academic literature as our previous reviews on past researches have given confirmation on the resource-based view of the firm, particularly on the resource-based strategy approaches $[25,26,34]$. The locus of resource-based view of the firm on organizational resources (tangible, intangible, and capability) could become the source for predicting and implementing strategy and advance organizational efficiency and effectiveness. These resources could drive forward the development of organizational competitive advantage as proven in current research. Thus, current research give contribution to the body of knowledge as our research give an indication that knowledge management and strategic leadership could serve as a foundation or key determinant in the attainment of organizational dynamic capability in implementing entrepreneurship strategy, which in turn have a role in improving organizational performance.

Overall, this research corroborates our knowledge that knowledge management and strategic leadership is a valuable intangible resources and become the source for organizational capability to implement the execution of better and suitable entrepreneurship strategy that is needed by organization in coping with rapid 
changes in their environment. Strategic implementation that have a ground on knowledge management and strategic leadership could become precious, rare, and hard to imitate organizational capability, which in turn could realize better organization performance and become the source for organizational competitive advantage.

\subsection{Practical Contributions}

Besides contributes to the academic literature, current findings have practical contributions with regard to the implementation of entrepreneurship strategy to achieve organizational performance and competitiveness even in public sector organization that so far have been characterized as been free from competition. Leaders and managers in the hospitals now have empirical support for their "theories in use" related to the effects of what is proven to be the antecedents for organizational performances in hospital. Moreover, they can use this information to better prepare for changes in performances and prevent future performance dips. Therefore, organizational leaders in public hospital would benefits in the following ways from this research.

First, it is time for hospital leaders (that become the object of our current research) to develop policy and mechanism that could drive knowledge management initiative in order so that these in the future could become organizational capability. Initiative of knowledge management that they could establish is in the form of knowledge acquisition, storing, sharing and application. Implementation of good knowledge management would very much determine hospital dynamic capability in handling stakeholder demand that become more critical and the changing hospital environment.

Second, as the success of strategy implementation is very much depends on the role of strategic leadership in driving and spearhead the entire potential resources amidst uncertainty and complexity in organizational operating environment. Therefore, it is worthily to give remainder to hospital leaders that organization knowledge that being processed through knowledge management cycle could become the source for their capability to have a role in implementing strategy. These in effect would leverage organizational capability as valuable and hard to imitate immobile resources that in turn would become the source for continuous organizational competitive advantage.

\subsection{Research Limitations}

Current research has given theoretical and practical contributions, yet these finding have its own limitations. Nevertheless, the following limitations represent opportunities for future research on this topic. Thus, in addition to the additional research limitations mentioned the following opportunities also exist.

First, major limitation in this study is related to the unit of analysis as we do not differentiate the characteristics of respondents group between general public hospitals that have attained the status as Public Service Agency (Badan Layanan Umum - BLU) with hospitals that have not achieved BLU status. This limitation have arisen due to the nature of the minimum requirement of sampling size within SEM analytical tool and have enforce us to disregard this differences even though we realize that these could give better significant information for the purposes of our research. Apart from this, researcher have try to cope with this limitation by conducting depth interview with directors and vice directors in the hospital that become the object of this research.

Second, future study would also benefit from additional informants from other position in the hospitals and/or private hospitals besides only relying from hospitals' leaders. These may be additional informants within the structural or functional unit (e.g. customer service or paramedics) or even informants from other organization. Representative limitation in the unit of analysis has impact on the generalization of research results in other organizations.

Third, minor limitation in this research is on the measurement of organizational performance from the perspective of leaders on the frequency of patients/customers complaints about hospital services. This kind of measurement would likely have bias responses, therefore to gain better objective information, future research should employed focus group session with few patients or customers. Customer data would also provide additional sources of data to evaluate the customer's perceptions of organizational performances, rather than relies heavily on leader's perception.

\section{REFERENCES}

[1]. Porter, Michael E. (1994). Competitive Advantage. Tim Penerjemah Binarupa Aksara. Keunggulan Bersaing. Jakarta: Binarupa Aksara. [2]. The Ministry of Health of the Republic of Indonesia (1992). Undang-Undang Republik Indonesia Nomor : 23 Tahun 1992 Tentang Kesehatan. Indonesia.

[3]. Peraturan Pemerintah Republik Indonesia Nomor 23 Tahun 2005 tentang Pengelolaan Keuangan Badan Layanan Umum. Indonesia.

[4]. Taylor, Bernard (1997). The Return of Strategic Planning - Once More with Feeling. Long Range Planning, Vol. 30, No. 3, pp. 334 to 344 .

[5]. Jauch, Lawrence R. \& William F. Glueck (2004). Strategic Management and Business Policy. $9^{\text {th }}$ Edition. McGraw-Hill Inc.

[6]. Shapiro, Janet, (2009). Strategic Planning Toolkit. http://www.google.com, Download Mei 2009.

[7]. Hitt MA, Ireland RD, Camp MS and Sexton DL (2002). Strategic Entrepreneurship: Creating a New Mindset. Blackwell Publishing. 
[8]. Athiyaman, A. \& R W Robertson (1995). Strategic planning in large tourism firms: an empirical analysis. Tourism Management, Vol. 16, No. 3, pp. 199-205.

[9]. Kuratko DF, Ireland RD and Hornsby JS (2001). Improving Firm Performance through Entrepreneurial Actions: Acordia's Corporate Entrepreneurship Strategy. The Academy of Mangement Executive. 15: 60.

[10]. Allanson, Jodee (2009). Intellectual Capital and Knowledge Management: A new era in management thinking?. http://www.google.com. Download, Mei 2009.

[11]. Galbreath, Jeremy (2005). Which resources matter the most to firm success? An exploratory study of resource-based theory. Technovation, 25 979-987.

[12]. Awad, Elias M. \& Hasan M. Ghaziri (2004). Knowledge Management. International Edition. New Jersey, Pearson Education Inc.

[13]. Pehrsson, Anders, (2008). Strategy antecedents of modes of entry into foreign markets. Journal of Business Research 61, 32140 .

[14]. Wiig KM (1997). Integrating Intellectual Capital and Knowledge Management. Long Range Planning. Vol. 30. 3: $399-405$.

[15]. Koenig MED (1998). From Intellectual Capital To Knowledge Management: What Are They Talking About? INSPEL 32. 4:. 222233.

[16]. Nonaka I (2006). Creating Sustainable Competitive Advantage through Knowledge-Based Management. http://www.google.com Download: September 2011.

[17]. Wiklund, Johan \& Dean Shepherd (2003). Knowledge-Based Resources, Entrepreneurial Orientation, And The Performance Of Small And Medium-Sized Businesses. Strategic Management Journal, 24: 1307-1314

[18]. Paiva, Ely Laureano, Aleda V. Roth, \& Jaime Evaldo Fensterseifer (2008). Organizational knowledge and the manufacturing strategy process: A resource-based view analysis. Journal of Operations Management, 26, 115-132.

[19]. Kok, Andrew, (2007). Intellectual Capital Management as Part of Knowledge Management Initiatives at Institutions of Higher Learning. Electronic Journal of Knowledge Management Volume 5 Issue 2, (181 - 192).

[20]. Marr, Bernard, Stephen Pike \& Göran Roos (2003). Intellectual capital and knowledge management effectiveness. Management Decision, 41/8, 771-781.

[21]. Chen, Chung-Jen \& Jing-Wen Huang. (2009) Strategic human resource practices and innovation performance - The mediating role of knowledge management capacity Journal of Business Research ,62, 104-114.

[22]. Eisenhardt KM and Martin JA (2000). Dynamic Capabilities: What are They? Strategic Management Journal. 21: 1105-1121.

[23]. Smith ME and Prieto IM (2008). Dynamic Capabilities and Knowledge Management: an Integrative Role for Learning? British Journal of Management. 19: 235-249.

[24]. Zheng W, Yang B and McLean GN (2009). Linking organizational culture, structure, strategy, and organizational effectiveness: Mediating role of knowledge management. Journal of Business Research. 6836: 1-11.

[25]. Barney JB (1991). Firm Resource and Sustained Competitive Advantage. Journal of Management. Vol. 17 No. 1: 99-120.

[26]. Barney JB, Wright M and Ketchen DJ (2001). The Resource-Based View of the Firm: Ten Years after 1991. Journal of Management. 27:625-641.

[27]. Bose R (2003). Knowledge Management-Enabled Health Care Management Systems: Capabilities, Infrastructure, and DecisionSupport. Expert Systems with Applications. 24: 59-71.

[28]. Teece DJ, Pisano G and Shuen A (1997). Dynamic Capabilities and Strategic Management. Strategic Management Journal. 18:7, 509-533.

[29]. Fairholm MR (2009). Leadership and Organizational Strategy. The Innovation Journal: The Public Sector Innovation Journal. 14: 1.

[30]. Serfontein K and Hough J (2011). Nature of The Relationship between Strategic Leadership, Operational Strategy, and Organizational Performance. Strategic Management Journal. 2011.

[31]. Zollo M and Winter S (2000). From organizational Routines to Dynamic Capabilities. Working Paper 99-07, University of Pennsylvania, Philadelphia.

[32]. Helfat CE, Finkelstein S, Mitchell W, Peteraf MA, Singh H, Teece DJ and Winter SG (2007). Dynamic Capabilities; Understanding Strategic Change in Organizations. Blackwell Publishing

[33]. Hitt MA, Ireland RD and Hoskisson RE (2006). Strategic management: Competitiveness and Globalization. Armand Hediyanto (translator). Manajemen Strategis: Menyongsong Era Persaingan dan Globalisasi. Jakarta: Erlangga Indonesia.

[34]. Grant, RM (1996). Toward a Knowledge-Based Theory of The Firm. Strategic Management Journal. Summer Special Issue 17: $109-122$.

[35]. Boccardelli P and Magnusson MG (2006). Dynamic Capabilities in Early-Phase Entrepreneurship. Knowledge and Process Management. Volume 13 Number 3: 162-174.

[36]. Teece DJ (2000). Strategies for Managing Knowledge Assets: the Role of Firm Structure and Industrial Context. Long Range Planning. 33: 35-54.

[37]. Choi B, Poon SK and Davis JG (2008). Effects of knowledge management strategy on organizational performance: A complementarity theory-based approach. The International Journal of management Science. 36: $235-251$.

[38]. Yang CC, Marlow PB and Luc CS (2009). Knowledge management enablers in liner shipping. Transportation Research Part E. 45: 893-903.

[39]. Abidi SSR (2001). Knowledge management in healthcare: towards 'knowledge-driven' decision-support services. International Journal of Medical Informatics. 63: 5-18.

[40]. Daud S and Yusoff WFW (2011). How Intelectual Capital Mediates the Relationship Between Knowledge Management Processes and Organizational Performance? African Journal of Business Management. Vol 5 (7), 2607-2617, April 2011.

[41]. Liu PL, Chen WC and Tsai CH (2005). An empirical study on the correlation between the knowledge management method and new product development strategy on product performance in Taiwan's industries. Technovation. 25: 637-644.

[42]. Huang, HC (2009). Designing a knowledge-based system for strategic planning: A balanced scorecard perspective. Expert Systems with Applications. 36: 209-218.

[43]. Chuang SH (2004). A resource-based perspective on knowledge management capability and competitive advantage: an empirical investigation. Expert Systems with Application. 27: 459-465.

[44]. Mojtahedzadeh R and Arumugam VC (2011). A Structural Relationship Between Knowledge Management, Innovation, and Performance of Iranian Industries: A Theoretical Approach. International Journal for Quality Research. 2011

[45]. Prahalad CK and Hamel G (1990). The core competence of the corporation. Harvard Business Review. 68(3): 79-91.

[46]. Liao SH and Wu CC (2010). System perspective of knowledge management, organizational learning, and organizational innovation. Expert Systems with Applications. 37:1096-1103.

[47]. Zott C (2003). Dynamic Capabilities and The Emergence of Intraindustry Differential Firm Performance: Insights from a Simulation Study, Strategic Management Journal. 24:97-125. 
[48]. Johannessen JA and Olsen B (2003). Knowledge management and sustainable competitive advantages: The impact of dynamic contextual training. International Journal of Information Management. 23: 277-289.

[49]. Ferdinand A (2006). Metode Penelitian Manajemen. Semarang: Badan Penerbit Universitas Diponogoro Indonesia.

[50]. Joreskog, K.G \& Sorbom, Dag (1993). Lisrel 8: Structural Equation Modeling with the Simplis Command Language, Chicago, SSI Inc.

[51]. Schumaker, R.E \& Lomax, Richard G. (1996). A beginner's guide to SEM, New Jersey: Lawrence Erlbaum Associates, Inc.

[52]. Hair JF, Black WC, Babin BJ, Anderson RE and Tatham RL (2006). Multivariate Data Analysis, 6th Edition. New Jersey. Pearson Prentice-Hall.

[53]. Ghozali, Imam, (2011). Model Persamaan Struktural: Konsep dan Aplikasi dengan Program AMOS 19.0, BPFE Universitas

[54]. Diponegoro, Semarang.

[55]. Dinas Kesehatan Provinsi Sulawesi Selatan (2011). Profil Kesehatan Provinsi Sulawesi Selatan Tahun 2010. Indonesia.

[56]. Solimun (2009). Memahami Metode Kuantitatif Mutakhir Structural Equation Modeling dan Partial Least Square. Malang. Program Studi Statistika FMIPA Universitas Brawijaya. Indonesia.

[57]. Holm U and Sharma DD (2006). Subsidiary marketing knowledge and strategic development of the multinational corporation. Journal of International Management. 12: 47-66.

[58]. Morales VJG and Montes FJL (2006). Antecedents and Consequences of Organizational Innovation and Organizational Learning in Entrepreneurship. Industrial Management \& Data Systems. Vol. 106 No. 1: 21-42.

[59]. Kaplan RS and Norton DP (2004). The Balanced Scorecard-Measures that Drive Performance. Harvard Business Review , January-February.

[60]. Kaplan RS and Norton DP (1996). The Balance Scorecard : Translating Strategy into Action. Boston: Harvard Business School Press. 